\title{
Challenges against Xi Jinping: an ASEAN Perspective
}

\author{
Abdullah Dahana Bina Nusantara University, Indonesia \\ Kelly Rosalin Bina Nusantara University, Indonesia
}

\begin{abstract}
Since the death of Mao Zedong in 1976 and Deng Xiaoping in 1997, factionalism and power struggle as the characteristic of leadership change in China has ended. Although factionalism still exists, it has been converted to collaboration among all factions within the Chinese Communist Party (CCP). The election of Xi Jinping to the presidency of the People's Republic of China (PRC) and to the position as General Secretary of the Chinese Communist Party (CCP) is therefore, as the result of cooperation among factions. This paper discusses various challenges, including nationalism as the most serious issue faced by Xi Jinping as a leader elected through compromise.
\end{abstract}

Keywords: Xi Jinping, factionalism, current Chinese nationalism.

\section{Introduction}

Change of leadership in countries practicing single party dictatorship is usually marred with power struggle. China, especially during the era of Mao Zedong (1949-1976) and Deng Xiaoping (1978-1997) was not exception to this rule. The causes of this phenomenon could be personal ambition, personal relationship among leaders, policy differences, fragmentation within the ruling party or more popularly known as factionalism, and other factors. Post-Mao/Deng China, however, seems not to follow this tradition anymore. Even if power struggle persists, it is no longer an "open warfare" known to the public but carried out within closed doors.

The election of Xi Jinping as General Secretary of the Chinese Communist Party
(CCP) as the result of the $18^{\text {th }}$ Congress of the party in November 2012 and his appointment as the President of the People's Republic of China (PRC) as the outcome of the $14^{\text {th }}$ National People's Congress (NPC) on March 14, 2013 consolidated his position, because in addition to the General Secretary of the CCP and the President of the PRC, he is also Chairman of the Military Commission. Transition of leadership from the $4^{\text {th }}$ to the $5^{\text {th }}$ generation of leader is therefore, complete and he is the most powerful person in the country of 1,4 billion people.

However, even though the change of leadership can be said as smooth. It doesn't mean that dissent among various wings of the Party has gone. In the past, Mao and Deng eliminated any different opinion within the ranks by harsh means. Series of 
political campaigns during the era of Mao(1949-1976) and 1989 suppression of Tiananmen protest are proofs on how in the past different opinions were denied.

Post-Deng/Mao leadership however, regard different opinions within ranks and files as positive as long as differing opinios do not develop into what Mao called as "antagonistic contradiction" (diwo maodun). Dissent is therefore tolerated as long as it is within "party lines." With the reemergence of factionalism, all big decisions, like the appointment of leaders, formulation of policies and their actualizations have to be discussed among factions.

Thus, the appointment of Xi Jinping as the leader of China, is therefore the result of compromise among factions. So is his policies. Based on the above considerations and facts, this paper will deal with challenges faced by $\mathrm{Xi}$ from both within and without the Party. These will include factionalism itself, $\mathrm{Xi}$ as the leader, and other factors he has to deal with.

This paper is written based on qualitative method and supported by data, both English and Chinese sources, available through library and internet search.

\section{Who is Xi Jinping?}

Western Press and of course China's own media have all dubbed Xi Jinping as a great diplomat who has been able to influence and gain the trust of all circles including the army. And because $\mathrm{Xi}$ is the descendant of let's say a "lord" in the dynasty of Chinese leaders, the Chinese press have named him the 'crown prince of the people'. Therefore, his appointment as Secretary General and as president this, was considered the right choice. As an "aristocrat" in the Chinese leadership, he is known to all the levels of the society, coupled with his impressive experience as a local and national official before occupying his present number one position.

Even Nicholas Kristoff (2013), a senior analyst that usually very critical perspectives of Chinese politics, has a positive impression of $\mathrm{Xi}$ Jinping and refers to him as a genuine reformer. Kristoff's opinion is based on several factors. First, $\mathrm{Xi}$ already has the spirit of a reformer implanted in him. He has inherited this from his father, the late $\mathrm{Xi}$ Zhongxun, a pioneer in economic development who openly condemns the Tian'anmen Square massacre in 1989. His mother chose to stay in Shenzhen, the most capitalistic region. Xi also sent his daughter to Harvard University, which, Kristoff said, proved his personal perception of the importance of English and his admiration for the American education system. Kristoff also speculate about the possibility of $\mathrm{Xi}$ releasing Liu Xiaobo, the critical author and Nobel Prize winner who is now languishing in jail. $\mathrm{X}_{\mathrm{i}}$ is also quite attentive and listens to public demands for a more transparent government. In fact, it is likely that he will abolish detention and punishment not preceded by judicial process. Kristoff further speculates that one of his main programs is to move the body of Mao which is preserved and now still on display in the mausoleum in Tiananmen Square. This is meant to eradicate the tradition of the cult of personality in the Chinese political system.

With the election of $\mathrm{X}_{\mathrm{i}}$ Jinping for a period of up to 10 years, the leadership of the party and the country has moved from $4^{\text {th }}$ to $5^{\text {th }}$ Generation. One of the characteristics of the $5^{\text {th }}$ Generation is the fact that they grew up, experienced and suffered during the Cultural Revolution(C.R.) launched by Mao (19661976). $\mathrm{Xi}$ is not exempt from this phenomenon because of the effects of the massive campaigns which occurred over the longest period in the history of Mao's 
leadership involving not only ordinary people but also the elite and their families. Even Deng Xiaoping, the architect of reform, and his family, suffered.

Holding various positions in the party leadership over that period of 25 years, his career continued to soar (Callahan, 2012). At first he was made the party secretary in Hebei province (1983-85), a backward and poor province. Then he was placed in the two prosperous provinces of Fujian (19852002) and Zhejiang (2002-07). In both provinces, he managed to launch an anticorruption campaign earning him the nickname "Mr. Clean."

In 2007, he was stationed in Shanghai and in this Metropolitan city of South China, he was considered to have succeeded in eradicating corruption. Due to those success stories he was called to Beijing to take over the party leadership. His career continued to rise with his appointment as vice president under $\mathrm{Hu}$ Jintao in March 2008.

Xi Jinping was born in Beijing in 1953 when his father was serving as head of the CCP's Central Propaganda Department and concurrently Deputy Minister of Education and Culture. Thus from his childhood $\mathrm{Xi}$ junior grew up in an elite community and school environment. He was a member of the so-called cynics of "the red aristocracy".

Westerners called them "princelings" or taizi in Chinese. Their number today is estimated at 300 people and they were the ones who used their positions or guanxi (connections) and networking to get quality education, which in turn secured them promising career paths in various fields.

However, $\mathrm{Xi}$ Jinping made an extraordinary move. When other members of the aristocracy plunged into business to reap abundant wealth, he used those connections to achieve a position in politics. When the C.R. erupted, Xi Jinping was just 15 years old, and as a "child of counterrevolutionaries" he was sent to the rural
Shaanxi province to do forced labor and to "learn from the peasants".

Towards the end of the Cultural Revolution, he avoided the frantic atmosphere of the capital because everyone was jockeying for a position to show case themselves as revolutionaries to get Mao's attention and get good positions in the party and government. His career continued to escalate and in 1983 he chose a career that would place him in the regions.

In rural Shaanxi, due to his organizational skills, he was able to secure the peasants' admiration who then appointed him party secretary of the village he was working in. Because of his capabilities, towards the end of the CR he obtained a recommendation to study at a university - an opportunity that is rarely obtained by a descendant of a "counterrevolutionary".

After earning an engineering degree from Qinghua University, one of China's leading university in Beijing, he was appointed Deputy Secretary of the CCP in Zhengding county, Hebei province, a place that was still very backward.

However, an opportunity arose which Xi so cleverly used. Zhengding had been used as the setting of a television series adaptation of the classic Chinese novel Honglou Mengor better known in the West as the Dream of the Red Chamber. The television serial which was spiced up with slight episodes of sex became very popular entertainment for the people. Xi cleverly turned the former TV series production set into a tourist object making Zhengding a successful tourist destination.

At that time all development programs were still under central planning and tourist destinations were limited to the Forbidden City, the Summer Palace, the Great Wall or Bataling (burial place) of the Ming emperors in Beijing. Because of his expertise, the Chinese media praised $\mathrm{Xi}$ as a person with a soul and spirit of a reformer and pioneer. 
Chinese media also praised $\mathrm{Xi}$ as a leader who embraced the philosophy of reform.

He continued what his father had pioneered by turning several cities in the south into "special economic zones." As the mayor of Xiamen in 1985 he encouraged the development of trade relations with Taiwan, which was just opposite the city. Xi held that position for 17 years and the economic chain between the two sides of the Taiwan Straits grew rapidly, in spite of their ideological opposition. In 2002 he brought this pioneering and reformist spirit to the Zhijiang province whose economy was growing smoothly.

Xi's leadership became more open and more reformist as reflected in his acceptance speech after his election, "Our people love life and hope for better education, steady jobs, better incomes, reliable social security, high standards of healthcare, as well as pleasant living conditions and environment. They expect their children to grow, work, and live better lives. People long for a life that is good and beautiful; that's what we must strive for" (Xinhua, 2012).

However, looking at the constellation of forces within the CCP, this praise may be somewhat exaggerated and its validity remains to be tested. There is still a lot that he needs to do in order to secure a productive leadership, and it obviously will take time. One of the main causes of this is none other than the factionalism within the $\mathrm{CCP}$ and various other challenges faced by him.

\section{Factionalism}

First it should be noted that the CCP is not a monolithic organization because it was always plagued by factionalism - this is no strange matter for a party with no rivals. In the Mao era there were only two factions which were always competing to determine policy. That is what experts outside China called a radical wing versus a moderate wing. And because the position of "Chairman Mao" as "a great leader of the revolution" was so dominant, radicalism always had the upper hand. Mao was therefore able to determine all policies freely and arbitrarily in all areas. The basis of all decision-making was also simple because the only reference was ideology.

Factionalism within the CCP is now much more complex. Its appearance is based on place of origins, education and training, and family background, although there are also groups who base their movement on ideology, especially Maoism. With the changing times, today in the postMao/Deng PKC there are least four main factions that competing each other. First is the Shanghai faction, known as Haipai, who gather around Jiang Zemin the PRC President and the CCP General Secretary during the 1992-2002 period, the former boss of the Shanghai CCP branch who was personally designated by the late Deng before his death to succeed him.

This faction is known as a champion for increasing the fruits of development. The main idea of the Shanghai group is essentially to keep the rate of economic development at the highest level. According to them, in order to maintain China's position as a world economic power when global competition is so tight, coastal areas should remain a priority as the machine of economic development.

This is the reason for their lack of concern for segments of society and regions of China that are still lagging behind in various fields. The concepts of this group are focused on the ideas of Jiang Zemin about the Three Representatives (san ge daibiao) which suggests to give the opportunity to entrepreneurs (read: capitalist) emerging after the launching of the reform, to become members of the CCP.

The Shanghai faction conceptually competed with the Young Communist 
League alumni group, one of the party's organizations whose primary objective was to prepare young people to become future leaders. In Chinese politics they are called the Faction League or tuanpai. Political analysts from the West often referred to them as "populists." The principles adopted by tuanpai are strengthening and consolidating the power of the central leadership, preserving and maintaining social stability, trying to distribute the fruits of development to eliminate significant differences between developed areas and underdeveloped areas, reducing the wide gap between the poor and the rich, and healing every social disease caused by the capitalization of the Chinese economy.

The group is led by former Party chief $\mathrm{Hu}$ Jintao and the concept of sharing the fruits of development was incorporated into his theory of creating a "harmonious society" (Leonard 2008). By using this discourse, they emphasized the importance of eliminating the gaping differences between the advanced and the backward regions and classes.

In addition to the two wings that hold opposing concepts, there is another group of younger people who are often referred to as the "princes". As a group within the Chinese political scene they got the name taizipai and Western observers referred to them as princelings. This group consisted of about 300 people with an average age of 5060 years. They were the sons/daughters of veterans who were comrades of Mao Zedong during the revolution to establish the CCP and the PRC.

Due to their position as the elite, they were fortunate to obtain a good education, and thanks to their guanxi, they successfully occupied important positions in the party and government. However, it should be noted that the strategic positions they occupied were not merely due to heredity or guanxi alone, but came with education, business, and experience they acquired as regional and central authorities or by being engaged in bureaucracy and business.

Bo Xilai, the former party boss of Chongqing, is another taizi figure who joined the group aspiring to maintain the teachings of Mao Zedong. He was eager to revive all Mao's teachings in the city he led. Unfortunately, behind this mask of Maoism, he was involved in degrading practices such as violations of human rights and corruption.

Linked to Bo Xilai, there was another elite group aspiring to preserve the teachings of the late Mao which emphasized ideological purity and the concept of equality in a classless society. The initiators of this movement are mainly senior revolutionaries who fear that the introduction of Deng's reforms will lead the society further away from the ideals of egalitarianism initiated by Mao. However, since the fall of Bo Xilai, the group is now in a much weaker position and their influence is receding. Thus in China's political arena there are now two main groups competing, the Shanghai faction and the faction supported by most of the league of the "princes". The Shanghai faction actually represents the concept of thinking of those outside the central government in Beijing, while the league reflects concepts of what must be done to manage the dynamics of the central government in developing the Chinese community in connection with China's entry into the arena of globalization.

Interestingly, the rivalry between these two schools has its own historical background. China is a country with such a vast territory that is has a diversity of geographic and human features. Thus, the existence of a central government in the North is a necessity for maintaining unity and political unity.

However, throughout history, political unity has often been disrupted and in some cases even developed into separatism. This occurred because some regions have their 
own ambitions and interests. Not infrequently this led them to achieve their ambitions by cooperating with outside forces. The case of warlordism (1924-1927) in China is an example of this pattern.

Tensions between the centralist and regionalist groups in the past have led to increasing conflicts between the North based in Beijing and the South led by Shanghai.

In the Mao era, Shanghai which is located in the South was known as a center of radical extremists under the leadership of Mao's wife, Jiang Qing while the North (Beijing) was a fortress of those who were stamped by Mao as bureaucrats and revisionists. When he felt his position was coming under escalating political pressure, Mao usually went to the South (Shanghai) to gather power and returned to Beijing to reclaim his influential position.

From a modern perspective, this conflict is characterized by the conflict of ideas between $\mathrm{Hu}$ Jintao and Jiang Zemin as reflected in the conflict between the ideas of the elitists versus the populists. However, if the first discourse was concerned with political opposition and the revolution, it has now turned into an economic discourse.

It is also important to keep in mind that although there are conceptual differences as a result of factionalism and opposing perceptions, every conflict is always debated behind closed doors and not transformed into antagonistic contradictions. This is important to ensure that the public sees the CCP as a solid and monolithic organization.

With the entrance of this factionalism, although it seemed that the Shanghai faction had the upper hand with the election of Xi Jinping, he still is the result of a compromise between the two factions. The distribution of power between the two factions is reflected by the election of $\mathrm{Xi}$ who had to be accompanied by a figure who would become prime minister, namely
Li Keqiang - a follower of tuanpai. Thus, the present is, in fact, a collective leadership. Gone are the days of dominant leaders or dictators of Mao and Deng Xiaoping's caliber.

\section{Various challenges facing Xi Jinping}

There are still many issues to be dealt with in China under the leadership of $\mathrm{Xi}$. As a person who has just made his entrance into the stage of leadership, he still needs time to consolidate his power. For that he still has to use " give and take" tactics in order to secure his position and to gain the support of the opposing factions, especially tuanpai and haipai. Based on the analysis that Xi Jinping's leadership is the result of a compromise, the following are the greatest challenges he will have to face.

\section{Politics and Ideology}

On the surface, the fall of Bo Xilai, who glorified Mao Zedong and desired to revive his teachings, was a blow to the Maoism revival movement. Hence, long before the opening of the Congress of the CCP, international observers predicted that the CCP congress would, among others, throw out Maoism as it was no longer relevant to the reform path taken by China.

However, $\mathrm{Mu}$ Chunshun, a Chinese analyst has come up with a different opinion. $\mathrm{Mu}$ endorses the idea that reform is no longer linked to Maoism, but he argues that observers are going too far or being too wishful when they think that the CCP will abandon Maoism. Because, said $\mathrm{Mu}$ futher, if they do that, its social impact will be huge. Disposing of Maoism will give the party a bad image in the eyes of the people, since if that happens, it will only go to show that the leadership of the Party is not monolithic. $\mathrm{Mu}$ said that the reason was that Maoism is the symbol of the unity 
of national leadership regardless of whether it is relevant or not to present-day China (Mu 2012).

Abandoning Maoism will also cause dissatisfaction among the army. It must be noted, $\mathrm{Mu}$ added, for example, that the doctrine adopted by the People's Liberation Army (PLA) has never been changed. It is the concept that "political power comes out of the barrel of the gun, but the gun must remain under the control of the Party" (Mu 2012).

It is important to keep in mind that the army, together with the Party and the bureaucracy, is one of the pillars of political power in China. PLA acts as the security guard or body guard of the Party, and it is evidenced by the way it did not hesitate to suppress demonstrations that threatened the Party in June 1989.

In other words, Maoism is still relevant. Those are the ideological challenges $\mathrm{Xi}$ will face. The speculation of Western observers were way off target. The results of the Party's Congress barely touched issues relating to ideology. However, this does not mean that the problem of ideology has been resolved, because the main problem lies in its position among the people and leaders of China.

The introduction of economic reforms that actually implement a capitalist system has resulted in a race to pursue material gains among the people and also widened the gap between the rich and poor, between urban and rural areas.

As a result there has been an erosion in ideology which in turn poses a threat to the position of the CCP because the ruling party's monopoly of power is based on the principles of Marxism-Leninism- Mao Zedong's Thoughts.

This threat will continue to overshadow the CCP even if it is trying to mask the implementation of this capitalist principle behind such terms as "socialism with Chinese characteristics" and"socialist market economy". Capitalism has pushed socialism/communism to the back seat and to overcome this tendency, the Chinese authorities have tried to promote nationalism among the masses and the youth, particularly after the 1989 Tian'anmen incident. But this has brought its its own problems which will be discussed in the final part of this paper.

\section{Economy}

The next challenge is the economy. Analysts generally say that in the last two years of the reform era that has actually been going on for more than three decades, there has been a tendency of a slowing down in China's economy.

This is not caused by mismanagement of the Chinese leaders, but rather caused by the global economic crisis, particularly in America and Europe as the lifeblood of China's economy depends to a greater part on exports to both those continents in particular. During the crisis, the two continents that are China's export targets are no longer able to absorb all the Chinese commodities as in previous years.

Economists believe that one solution to overcome this is to increase the ability of domestic consumers to accommodate China's own products. The old slogan "made in China" must now be replaced by a new "made by Chinese for the Chinese ". However, to achieve this, the government should first of all make efforts to increase the purchasing power of domestic consumers. The population which is approaching 1.4 billion people is a paradise for their own products.

However, increasing the prosperity of the grassroots will be a subject of debate among the elite, i.e. those who want to enlarge the "pie of development" in opposition to the populist faction that aspires to improve the living standards of the people by distributing the results of 
development more evenly. But, given the importance of strengthening the purchasing power of domestic consumers, there is a possibility that Xi's economic policy will lean towards the League faction.

However, in order to maintain the image of a monolithic leadership, he will also have to pay attention to the Shanghai faction. According to analysts, Xi's economic policy will be more inclined towards the Shanghai faction, although he also has to listen to the expert advice of the tuanpai (Steinbock 2012).

This has to do with the collective leadership system will inevitably require $\mathrm{Xi}$ to consider the opinions of his colleagues. Closely related to the question above, is how to educate Chinese consumers to better appreciate their own domestic products. Changing consumer attitude is quite a big challenge.

Restructuring the roles of state enterprises in the Chinese economy will also pose a challenge. According to statistics, at present, state owned enterprises account for more than $60 \%$ of the economic activity and circulation of money. In other words, the PRC are implementing a state capitalist system. And similar to conditions in other developing countries, state enterprises are also a source of corruption in China.

There are many more economic problems that Xi must face. Among others, the swelling local government debts and the aging population of China which will become a burden for the economy. It has been argued that the one family one child policy should be changed into two children for each family. However, this change in policy will lead to huge economic and social consequences because even with the present policy the country's total population has reached approximately 1.4 billion.

\section{Demands for "Democratization"}

Increasingly strong demands of the grassroots for a system of government that is more open, more "democratic" and more attentive to public interests also need to be dealt with. Dissatisfaction was associated with a violation of civil rights, such as punishment without trial, the appropriation of the people's rightfully owned land in the form of "freeing" of land for the sake of "development" and various other violations. It should also be noted, there were violations of the rights of the minorities in Tibet and Xinjiang.

This is closely linked with the constitution that had actually been approved by the National People's Congress (NPC) in 1982. The process began with disappointment and upheavals over various violations of laws during the Cultural Revolution campaigns (1966-1976).

CCP leaders who survived the atrocities and violence that took place during the campaign concluded that it was essential for China to have a constitution that respects individual rights and also ensures that rulers be subject to this rule of law. The times when tyrants could exercise power and control irresponsibly should be terminated. It should be noted that this attitude was not implemented as a direct criticism of the policies adopted by Mao.

In fact the constitution was never effective and various offenses were still committed by people in power. But, now the demands for the realization of a state and a government that follow the rule of law are becoming more forceful. Actually these demands are a reaction to $\mathrm{Xi}^{\prime}$ 's various speeches which invariably stressed the need to enforce the enactment of the constitution.

In line with this, approximately 72 intellectuals submitted a petition to push the Party to uphold the constitution." We are in agreement that constitutionalism should be a central issue in the reform 
program," said Zhang Qianfan, professor of law at Beijing University who drafted the petition.

He further stated that economic factors were far too dominant in the reform program in the past. But, from experience over the last 20 years, Zhang said that the economic reforms could go wrong if they were not offset by meaningful political reforms which imply constitutional reform (Wong and Ansfield 2013).

The echoes of these demands were reverberated even louder by the newspapers and other media supporting reforms, including a journal issued by the central party cadre school once headed by Xi Jinping. But the petitioners were actually stimulated by a speech in which Xi said that among others, that the constitution should be a legal weapon for the people to defend their rights.

Deng Yuwen, a newspaper editor, has boldly said he has not seen $\mathrm{Xi}$ take any concrete steps to make the constitution work. "The Constitution cannot be implemented by mere talk,"said Deng (Wong and Ansfield 2013).

Indeed, since occupying the highest position in the country, although he has talked a lot about the importance of freedom, $\mathrm{Xi}$ has placed more emphasis on the importance of internal party discipline. He keeps reminding people that China should avoid repeating the fate that led to the break up of the Soviet Union.

Thus, the issue of freedom will again stumble into something very basic: Deng Xiaoping only introduced economic reforms since his ultimate goal was to preserve the power of the communist party. His successors continue this principle.

Social Issues

Because she has embraced the capitalist system, China has also been infected by the various diseases of capitalism. Take for instance, the gap in wealth between the coastal and inland regions. Actually, the government has made many breakthroughs to bridge the gap between the rich regions and the backward regions, particularly by building infrastructures.

Many remote areas are already open and connected to the urban areas (Johnson 2013). However, China is so vast with a population so large that many more efforts should be made to overcome this. In the Mao era, political campaigns were carried out to bridge the urban-rural gap. Now this method can no longer be used.

Closely related to the above is the richpoor gap. Only few Chinese people with the capacity to be global player that are able to enjoy the fruits of economic reform. In a capitalist system in which the rules of the game have not been fixed like that of China, money synergizes with power.

There are allegations made by the lower classes that in such a wild system, where the rich are getting richer and the poor poorer, a contributing factor is corruption. This will all lead to jealousy and social unrest. How to overcome a habit that has been embedded in the system for over 20 years is a big challenge for the CCP and its leaders.

Another common phenomenon is the clearing of slum areas in urban districts to be turned into modern residential areas and business centers. The evictions to free those slum areas have resulted in protests and social tensions. One of the events that got the world's attention is the displacement that occurred in a small town, Wukan, near Guangzhou, in the Guangdong province. As a result of the massive protests of the local residents, the evictions were postponed. This event is described as the people's victory over the capitalization of residential areas. 
Party Relations and the Masses

Xi Jinping faces another big task no less important, namely, putting back the CCP in the hearts of the people. In the past, especially when Mao was still alive, the party was still very close to the people. To maintain such a relationship Mao created a concept known as the mass line (cunzhong zhongxian). The cadres were instructed to listen to all complaints and wishes of the masses so that the party would not be isolated from the people. Internally, Mao applied the Leninist principle known as democratic centralism (Waller 1981).

The concept demanded the leadership of the Party to inform all levels of administration under their supervision of the plan-making policies to be pursued. Thus, all units were asked to discuss the party's policy plans and submit suggestions or objections. However, once a decision had been taken, all party elements ranging from the highest to the lowest units had to comply with the policies and implement them.

During the time when the CCP was in control, in the framework of the mass line concept, Mao always involved the masses in all political campaigns pertaining to both domestic and international issues.

Starting in the early 1950s until his death in 1976, Mao and his supporters launched a series of mass campaigns. As a result, on the one hand people became very literate in politics, but on the other hand they also became tired of the never-ending mass campaigns.

After Mao's departure and after Deng Xiaoping came to power, the number of mass campaigns was greatly reduced. However, because the masses were not involved, politics became an elite movement.

Occasional mass action was launched but under very tight control. An example of this was the anti-American demonstrations in 1999 when American planes accidentally bombed the PRC Embassy in Belgrade. However, the demonstrations were eventually stopped because there were visible signs that the Chinese government was also becoming one of the targets of the demonstrations.

Strict control over all kinds of mass action was applied after the 1989 Tian'anmen demonstrations which almost caused the breakup of the CCP due to internal conflicts. Thus, one of the major tasks that $\mathrm{Xi}$ Jinping must shoulder is putting the party back in the hearts of the people without threatening the CCP monopoly of power.

\section{Nationalism}

Nationalism emerged at the end of the 19th century when there was a hot debate among Chinese elite regarding the question on how to come out of national crisis and humiliation. All parties basically agreed that the fundamental reason for the crisis was the presence of Western colonialism and the weakness of Qing Dynasty.

On how to come out of the crisis, however, they have different opinions. Some thought that the main cause was the backwardness of Chinese military and weaponry power, and thus they campaigned for "learning from foreigners" (read West) or yangwu yundong and "Self Strengthening Movement." Others urged for "keeping Chinese thinking as national identity while using Western technology for practical means"(Zhongxue wei ti, Xixue wei yong).

There were also groups which advocated anarchism, while two Confucian scholars, Kang Youwei and his disciple Liang Qichao, spread the idea of constitutional monarchy system copying from England. Of all the popular ideas which came out at that time, mostly wanted 
to maintain monarchy system. It was during these fierce debates Dr. Sun Yatsen came up with a radical thought: the Qing Dynasty was a foreign conquerer and a colonialist power, it had to be overthown and China should establish a republic state based on Chinese nationalism.

It was under the leadership of Dr. Sun the Qing Dynasty was abolished by 1911 Revolution (Xinhai Geming) and a republic was later created (Lin 2011). However, Chinese nationalism remained buried for quite a long time and only reappeared on Mainland China in the last 30 years, particularly after the introduction of Deng Xiaoping's reform. It is important to note that since the PRC was founded in 1949, the only ideology for the government and the people is Communism/Socialism or better known as Marxis-Leninism and the Thought of Mao.

However, Marxism-Leninism and the Thought of Mao seems not have anymore place in the hearts of most of the people as a result of Mao's policies that imposed the principle of "politics in command" especially after 1957.

Since then for the next 20 years, Mao for the sake of realizing his ideals of creating a socialist society, launched a series of mass campaigns ranging from the Great Leap Forward (Da Yuejin), the Socialist Education Movement, the People's Communes (Renmin Gongshe), which peaked in 1966 with the start of the Cultural Revolution (Zichanjieji Wenhua da Geming).

The last campaigns was the greatest, longest (about 10 years), and with a large number of victims and only stopped after Mao's death. During the series of mass campaigns all the elements of society that opposed Mao were considered "counterrevolutionaries" and put to jail or killed. The victims included his comrade in arms in fighting to establish the CCP and the PRC.

Only two years after Mao died in 1976, after successfully eliminating the Maoists,
Deng Xiaoping introduced reform and opening of China up as well as the capitalist economicsystem (Tyler 1997). As a result, because of the cruelty of the Maoist system, almosteveryone in China welcomed reform and was encouraged to pursue material gains. Consequently, socialist ideologies were marginalized.

With the end of the Cultural Revolution era and the introduction of the capitalist system, some segments of Chinese society, particularly students and intelectuals tempted to follow an Western liberal democracy. This culminated in a series of demonstrations during the Spring and Summer of 1989, followed by the Tian'anmen massacre, in June 1989. That is understandable because Deng's main objective to introduce reforms was precisely to preserve and strengthen $\mathrm{CCP}^{\prime}$ 's grip over Chinese society.

In the aftermath of the Tian'anmen massacre, nationalism that had long been neglected secured a place for itself again. The state played an important role in its resurgence. The general public, especially school children, students and young children were brainwashed with nationalism and a sense of pride in being Chinese.

The Army, wherever they are, usually has a high sense of nationalism and patriotism. The switch to nationalism was relatively easy, because the Chinese are traditionally known as a people who are highly chauvinistic. The success of China hosting the Olympics Games in 2008, was regarded as the pinnacle of the Chinese government's success in inculcate this nationalist sentiment.

However, an overdose of nationalism will lead to xenophobia and could backfire. Anti-foreign nationalism could turn into a mass movement against the government if the authorities are considered not "assertive" enough or seen as to be weak under foreign pressure. For example, in 
1999 when the American bombers accidentally dropped bombs on the Chinese embassy, mass anti-American demonstrations were staged in many major cities. American representative offices were vandalized; pelted with stones and Molotov cocktails (Sina News 1999).

Demonstrations became increasingly violent when the Chinese government seemed to lack force in its protest against America. Worried that the demonstrations would turn into anti-government such as those in Tian'anmen in 1989, the authorities took immediate measures to stop the mass action. Since then it seemed that all the mass movements were orchestrated by the government.

\section{Conclusion}

This paper deals with series of obstacles faced by Xi Jinping as new Chinese leader and we can conclude that there are many enormous challeges he is facing. One of the obstacles that he has to deal with is the fact, although seems to be powerful, he is still a leader emerged as the result of compromise among factions within the CCP. Consequently, decision making will take more time since it has to be discussed among factions.

So, how should Xi Jinping, as the new leader, face public pressure in China's conflict with Southeast Asian countries and Japan over overlapping claims in the South China Sea and East China Sea? In accordance with the principle of collective leadership and the principle of "consultation and consensus", in all issues, both domestic and international, he must obtain the consent of both factions holding political power today. Whatever steps $\mathrm{Xi}$ takes, he must have the blessings of all the factions and because he has only been in this new leadership, Xi needs time to spread his influence among party leaders as well as the army and masses.

There are opinions that the claim on the South China Sea is a legacy of Hu Jintao. There is a custom in China for a leader stepping down to leave "a legacy" to be continued by his successor. Mao's legacy was his thoughts, Deng Xiaoping's was his reforms, Jiang Zemin left his three representations, and $\mathrm{Hu}$ Jintao bequeath the harmonious society concept and claims over the Diaoyutai (Senkaku).

Thus, in this case Xi seems to be facing a difficult choice. With the nationalist sentiment surging, especially among the youth and army, taking no compromise will put him in a difficult position. If he takes a step that is considered a compromise, he will have to answer to his own people.

If he chooses confrontation, not only the will the world suffer from the consequences, but also China itself. The strategy he is using in ASEAN is divide et impera or divide and rule. Through economic aid, $\mathrm{Xi}$ has successfully "persuaded" Cambodia to dismiss the agenda to discuss the issue of overlapping claims in the South China Sea at the ASEAN summit recently.

But, if this policy is maintained, neighboring countries who strongly support the agenda, especially Vietnam and the Philippines, will certainly turn to the US. China gain the image of a big country that wants to restore its hegemony in the Southern Hemisphere.

A confrontational attitude would also be contrary to the principle of peaceful rising propagated since China's rise to superpower, both in terms of military and economic power. The principle states that China'sascent into a world power is to seek peace through the principle of peaceful coexistence with other countries, not to practice hegemony. The situation in China faced by $\mathrm{Xi}$ Jinping regarding the role of ideology is reflected in an ancient saying: 
nationalism can be a double-edged sword. It can be used against enemies, but it also can injure the owner.

\section{About Author}

Abdullah Dahana is a Professor of Chinese Studies within the Faculty of Humanities, Bina Nusantara University. He can be contacted at dhn705@gmail.com.

Kelly Rosalin is a junior lecturer within Department of Chinese Studies, Bina Nusantara University.

\section{References}

Kristof, N. (2013). Looking for a Jump-Start in China. [online] Available at: http:/www.nytimes.com/2013/01/06/opi nion/sunday /kristof-looking-for-a-jumpstart-in-china.html?_r=0 [Accessed 24 Apr. 2014].

Callahan, W. (2012). Who is Xi Jinping, and where will he lead China?. [online] openDemocracy. Available at: http:/www.opendemocracy.net/william -callahan/who-is-xi-jinping-and-wherewill-he-lead-china [Accessed 24 Apr. 2014].

News.xinhuanet.com，(2012). 习近平: 人民 对美好生活的向往就是我们的奋斗目标 中国共产党第十八次全国代表大会 $(X i$ Jinping: Renmin dui meihao shenghuo de xiangwang jiushi women de fendou mubiao - Zhongguo Gongchandang di shiba ci quanquo daibiaohui). [online] Available at:http: //news.xinhuanet.com/18cpcnc/2 012-11/15/c_123957816.htm [Accessed 24 Apr. 2014].

Leonard, M. (2008). What Does China Think?. 1st ed. United States: Public Affairs.

$\mathrm{Mu}$, C. (2012). Why the CCP Won't Abandon Mao Zedong Thought. The Diplomat. [online] Available at: http:/thediplomat.com/2012/11/whythe-ccp-wont-abandon-mao-zeodongthought/[Accessed 3 Jun. 2014].

Steinbock, D. (2012). From InvestmentDriven Growth to Consumption: Chinese Leadership Transition. ChinaUS Focus. [online] Available at: http://www.chinausfocus.com/politicalsocial-development/from-investmentdriven-growth-to-consumption-chineseleadership-transition/ [Accessed 4 Jun. 2014].

Wong, E. and Ansfield, J. (2013). Reformers Aim to Get China to Live Up to Own Constitution. New York Times.

Johnson, I. (2013). China's Great Uprooting: Moving 250 Million Into Cities. New York Times.

Waller, M. (1981). Democratic Centralism: An Historical Commentary. 1st ed. [ebook] Manchester: Manchester University Press, p.95. Available at: http:/books.google.co.id /books?id=ahg NAQAAIAAJ\&printsec $=$ frontcover $\# \mathrm{v}=\mathrm{O}$ nepage $\& \mathrm{q} \& \mathrm{f}=$ false [Accessed 4 Jun. 2014].

Lin，J. (2011). 辛亥革命与中华民族的觉醒 (Xinhai Geming yu Zhonghua Minzu de Juexing). 1st ed. Guangzhou: Guangdong Renmin Chubanshe, pp.93.

SINA NEWS, (1999). 中国驻南联盟大使馆8

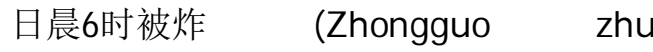
Nanlianmeng dashiguan 8ri chen 6shi bei zha. [online] Available at: http://news.sina.com.cn/world /9905/050 817.html [Accessed 5 Jun.

Tyler, P. (1997). Deng Xiaoping: A Political Wizard Who Put China on the Capitalist Road. New York Times. [online] Available at: http://www.nytimes.com/learning/gener al/onthisday bday 0822.html [Accessed 5 Jun. 2014]. 